\title{
Features of the formation of primary production in small lakes of various natural zones in the south of Western Siberia
}

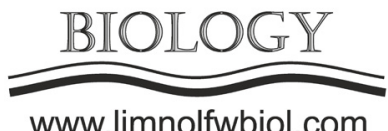

www.limnolfwbiol.com

\author{
Zarubina E.Yu.
}

Institute for Water and Environmental Problems, Siberian Branch of the Russian Academy of Sciences, Molodezhnaya St., 1, Barnaul, 656038, Russia

\begin{abstract}
The territory of the south of Western Siberia is located in several natural, hydrological and climatic zones. Long-term studies (2008-2019) of small lakes in the region, located on the plain from the steppe zone to the taiga zone, as well as in the mountain-forest and mountain-steppe zones, have been carried out. It is shown that the leading role in the formation of primary production in lakes is played by zonal factors, such as the ratio of elements of water and heat balance; the chemical composition of lake waters, etc. The characteristics of productivity and characteristics of small lakes of different hydrological and climatic zones are given.
\end{abstract}

Keywords: primary production, destruction, phytoplankton, macrophytes, natural zone

\section{Introduction}

The formation and accumulation of organic matter is one of the links in the general circulation of matter and energy in a reservoir, which determines its bioproductivity. The amount of organic matter accumulated in the reservoir depends on the ratio of production and destruction processes. With a decrease in the efficiency of utilization of organic matter, the pasture cycle of the trophic chain changes to a detrital one, which leads to the accumulation of detritus in the ecosystem and an increase in the trophicity of the reservoir.

The territory of the south of Western Siberia is one of the lacustrine regions of Russia; there are more than 20000 lakes, which differ in morphometry, hydrological and hydrochemical regimes, the nature of overgrowth and productivity of aquatic phytocenoses. The ratio of the elements of the water and heat balance, which determines the level, hydrochemical and ice regimes and other features of the lakes of the region, strictly obey the geographic zonality (Shnitnikov, 1957).

\section{Material and methods}

The work was carried out on the basis of longterm studies (2008-2019) of the productivity of aquatic phytocenoses of small lakes located in various natural (forest, forest-steppe, steppe, mountain-forest, mountain-steppe) and hydrological and climatic zones of the south of Western Siberia (Zarubina, 2013;
Strakhovenko et al., 2019; Zarubina and Fetter, 2019; Zarubina and Sokolova, 2019).

The determination of the primary production of plankton and the destruction of organic matter (OM) was carried out by the flask method in oxygen modification. The study of the productivity of macrophytes was carried out by standard methods (Rukovodstvo..., 1992).

During the research, the following indicators were also measured: depth, transparency, color, water temperature, $\mathrm{O}_{2}$ concentration and organic matter content (according to $\mathrm{BOD}_{5}$ ).

\section{Results}

The value of the primary production (PP) of phytoplankton in the studied lakes varied over a wide range from 0.01 to $2.21 \mathrm{mgO}_{2} / 1$ * hour. The greatest values PP were noted during the period of mass development of cyanobacteria in the lakes of the forest (1.29- $0.42 \mathrm{mgO}_{2} / 1$ * hour) and forest-steppe (0.59- 0.63 $\mathrm{mgO}_{2} / 1 *$ hour) zones. Low phytoplankton production was observed in mountain forest $\left(0.12 \pm 0.04 \mathrm{mgO}_{2} / 1\right.$ * hour) and taiga lakes $\left(0.21 \pm 0.09 \mathrm{mgO}_{2} / 1 *\right.$ hour $)$.

The rate of OM destruction varied from 0.02 to $1.93 \mathrm{mgO}_{2} / 1$ * hour. The most intense destruction processes took place in the lakes of the forest zone (1.11 - $0.39 \mathrm{mgO}_{2} / 1 *$ hour). A low rate of destruction is noted in the lakes of the taiga zone $\left(0.13 \pm 0.07 \mathrm{mgO}_{2} / 1\right.$ * hour) and in mountain-forest lakes (0.11 \pm 0.06 $\mathrm{mgO}_{2} / 1 *$ hour). 
The lakes of the region differ significantly in the degree, nature of overgrowth and the level of productivity of macrophytes. The most productive are the "macrophyte" lakes located in the forest-steppe zone. These lakes are characterized by the abundant development of both submerged (hydrophytes) and semi-submerged (helophytes) vegetation, massive overgrown or overgrown type of overgrowth. The area of overgrown lakes ranges from $30-40 \%$ to $50-90 \%$. Annual production of hydrophytes - from 416 to 2660 $\mathrm{g} / \mathrm{m}^{2}$, helophytes - from 960 to $2438 \mathrm{~g} / \mathrm{m}^{2}$. In lakes with an overgrowth type, the production of helophytes reaches $7500 \mathrm{~g} / \mathrm{m}^{2}$ per year.

In the lakes of the taiga and mountain-steppe zones, the vegetation cover is formed mainly by hydrophytes. The overgrown area is from $10-15$ to $30 \%$. The lowest production of macrophytes was noted here. In taiga lakes, the annual production of hydrophytes ranges from 196.8 to $675 \mathrm{~g} / \mathrm{m}^{2}$, in mountain steppe lakes - from 235 to $970 \mathrm{~g} / \mathrm{m}^{2}$.

\section{Discussion and conclusions}

In most lakes, production processes were more intense than destructive ones. In some lakes of the forest-steppe and steppe zones, the rate of phytoplankton production was 3-6 times higher than the rate of destruction. In such lakes, the processes of organic substance formation prevail over the processes of its decomposition, and in the reservoir, organic matter accumulates in bottom sediments.

The nature of the formation of autochthonous organic matter in lakes was largely associated with zonal factors, in particular, the ratio of water and heat balance elements, which determine the features of the hydrological, hydrothermal, and hydrochemical regimes of the region's lakes. The largest value of primary production was observed in the lakes of the forest and forest-steppe zones, which, according to (Mezentseva, 2009), are located in the zone of optimal moisture and heat supply. Basically, the lakes of these zones are fresh or slightly saline with a neutral reaction of the environment and a high content of nutrients in the water.

Low-productive taiga lakes are located in the zone of excessive moisture and insufficient heat supply, and mountain-steppe lakes are in the zone of insufficient moisture and insufficient heat supply. These are, for the most part, oligotrophic or dystrophic lakes with a low content of nutrients in the water. In addition, in taiga lakes, the acidic reaction of the environment is probably the limiting factor $(\mathrm{pH}=5.8 \pm 0.6)$.

\section{Acknowledgements}

The work was carried out within the framework of the state task of the IWEP SB RAS.

\section{References}

Mezentseva O.V. 2009. A method for identifying the zone of economic moisture optimum. Geografiya i Prirodnyye Resursy [Geography and Natural Resources] 1: 159-162. (in Russian)

Rukovodstvo po gidrobiologicheskomu monitoringu poverkhnostnykh ekosistem [Guidelines for hydrobiological monitoring of surface ecosystems]. 1992. St-Petersburg: Gidrometeoizdat. (in Russian)

Shnitnikov A.V. 1957. Ozera Zapadnoy Sibiri i Severnogo Kazakhstana i mnogovekovaya izmenchivost' uvlazhnennosti stepey [Lakes of Western Siberia and Northern Kazakhstan and centuries-old variability of moisture content of the steppes]. Trudy Laboratorii Ozerovedeniya [Proceedings of the Laboratory of Lake Science] 5: 5-63. (in Russian)

Strakhovenko V.D., Ovdina E.A., Malov G.I. et al. 2019. Genesis of organomineral deposits in lakes of the central part of the Baraba lowland (south of West Siberia). Russian Geology and Geophysics 60: 978-989. DOI: 10.15372/ RGG2019093

Zarubina E.Yu. 2013. Primary production of macrophytes of three different types of sapropel lakes in the south of Western Siberia (within the Novosibirsk region) in 2012. Mir nauki, Kul'tury i Obrazovaniya [World of Science, Culture and Education] 5(42): 441-444. (in Russian)

Zarubina E.Yu., Fetter G.V. 2019. Processes of production and destruction of organic matter in mountain lakes of the Russian Altai. In: XII Congress of the Hydrobiological Society of the Russian Academy of Sciences, pp. 165-166. (in Russian)

Zarubina E.Yu., Sokolova M.I. 2019. The role of zonal factors in the formation of productivity of small lakes in the south of the Ob-Irtysh interfluve. In: International Conference Lakes of Eurasia: Problems and Solutions, pp. 80-84. (in Russian) 